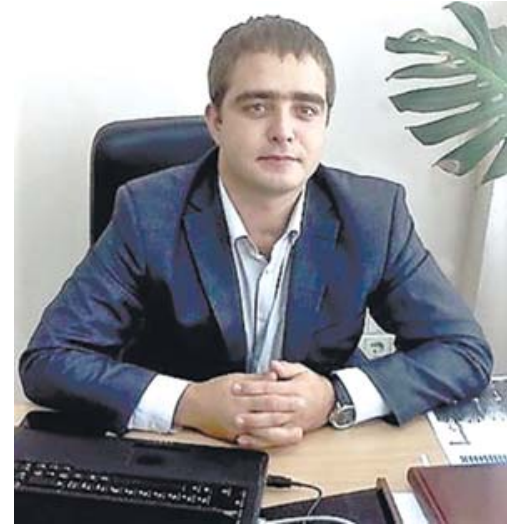

ОДАРЧЕНКО

Роман Сергійович -

доктор технічних наук, старший науковий співробітник відділу інтелектуального управління Міжнародного науковонавчального центру інформаційних технологій та систем НАН України та МОН України

\section{МЕТОДИ ТЕСТУВАННЯ ТА ПІДВИЩЕННЯ ЕФЕКТИВНОСТІ СТІЛЬНИКОВИХ МЕРЕЖ 5G}

\author{
За матеріалами наукового повідомлення \\ на засіданні Президії НАН України \\ 15 вересня 2021 року
}

Для підвищення ефективності стільникових мереж в Україні можна і потрібно використовувати вже набутий досвід розвинених європейських крайн, при цьому удосконалюючи його та розробляючи нові рішення. У статті наведено основні результати, отримані під час виконання робіт за трьома науковими проєктами. Так, у рамках двох проєктів за програмою «Горизонт-2020» (5G-Xcast, 5G-TOURS) одержано нові результати, які дали змогу підвищити ефективність стільникових мереж 5G. Третій проєкт (5GASP) тільки розпочався, проте має амбітну мету, яка полягає в розробленні платформи для автоматизованого тестування та валідацї додатків, призначених для використання у мережах п'ятого покоління (5G).

Ключові слова: 5G, 5G-TOURS, 5G-Xcast, 5GASP, Horizon 2020, стільникові мережі зв'язку, підвищення ефективності.

Одним з найактуальніших та найважливіших завдань сьогодення для більшості країн світу є формування і розвиток інформаційного суспільства [1]. У Свропейському Союзі пріоритетом у розбудові сучасної інформаційної інфраструктури є створення загальноєвропейської системи високошвидкісного мобільного широкосмугового доступу до ресурсів мережі Інтернет на всій території співтовариства. Йдеться про широкосмуговий зв'язок на основі використання мобільних технологій четвертого (4G, від англ. generation - покоління) та п’ятого (5G) поколінь. Саме тому на вирішення питань впровадження технологій $5 \mathrm{G}$ спрямовано сьогодні цільові зусилля найбільших світових операторів стільникового зв'язку (наприклад, Orange, Vodafone та ін.).

Загалом вплив цих технологій на розвиток сучасного суспільства неможливо переоцінити. Наразі мобільний зв'язок став нормою, а мобільні технології є надзвичайно популярними, затребуваними у суспільстві і розвиваються стрімки- 


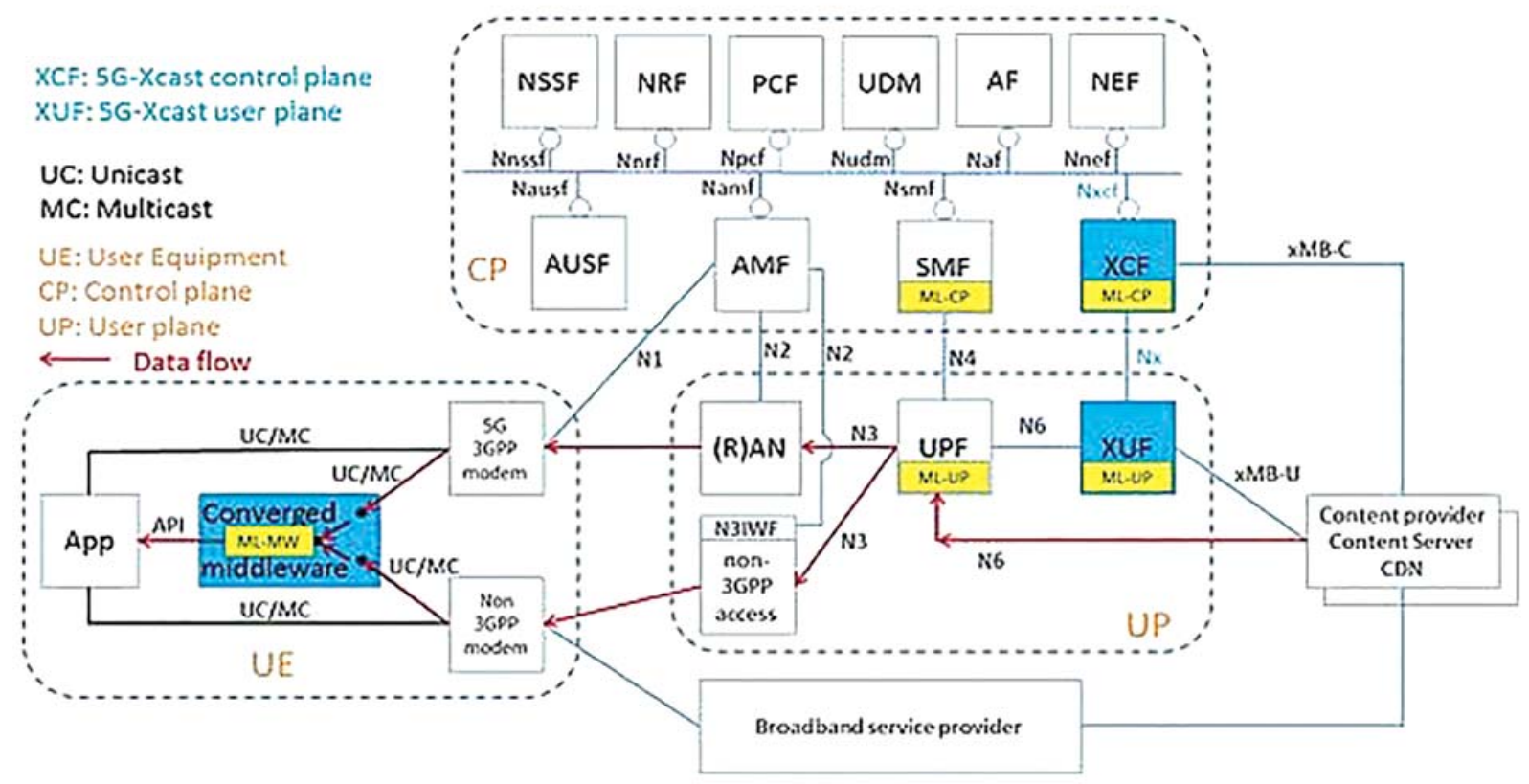

Puc. 1. Архітектура ядра мережі 5G, розроблена в рамках проєкту 5G-Xcast

ми темпами. Еволюцію систем стільникового зв’язку схематично можна описати так:

• покоління 0G (з 1946 р.) - поява мобільного телефонного зв'язку;

- покоління $1 \mathrm{G}$ (1980-ті роки) - аналогові стільникові системи радіозв'язку загального користування (NMT, AMPS, TACS);

• покоління 2G (1990-ті роки) - глобальний стандарт цифрового мобільного стільникового зв'язку (GSM) та радіозв'язку з розділенням каналів за часом і частотою (CDMA);

- покоління 3G (2000-ні роки) - універсальна система мобільного стільникового зв'язку UMTS, заснована на технології WCDMA;

- покоління 4G (2010-ті роки) - мобільний протокол передачі даних LTE Rel. 10, стандарт бездротового зв'язку WiMAX Rel. 2.0.

Поряд зі зростанням кількості різних пристроїв, підключених до глобальної мережі, з'являються все нові популярні послуги (передача відео високої чіткості 4K, 8K, віртуальна реальність (virtual reality - VR), доповнена реальність (augmented reality - AR), концепція Connected Cars тощо), які висувають принципово нові вимоги до цільової ефективнос- ті стільникових мереж, зокрема потребують зменшення затримок, збільшення необхідної пропускної здатності та ін. При цьому слід зазначити, що сучасний світ нині переживає період експоненціального збільшення масивів даних, які передаються різними мережами, а тому наявна інфраструктура вже не завжди здатна ефективно справлятися з такими обсягами мобільного трафіку [2]. Очевидно, найближчим часом наявні мережі не зможуть забезпечити необхідну якість обслуговування мобільних абонентів, автомобілів та пристроїв «нтернету речей». Ось чому настав час повсюдного розгортання нових мереж п'ятого покоління.

3 огляду на все вищесказане, можна стверджувати, що розвиток інфраструктури широкосмугового доступу до ресурсів мережі Інтернет на всій території Свропи та України, зокрема доступу на базі створення високошвидкісних мереж 5G і підвищення ефективності їх функціонування, є вкрай актуальним та перспективним завданням.

Дослідницькі проєкти в галузі 5G. Як уже зазначалося, кількість пристроїв, підключених

ISSN 1027-3239. Visn. Nac. Acad. Nauk Ukr. 2021. (10) 
Puc. 2. Динамічно адаптована мережева архітектура $5 \mathrm{G}$

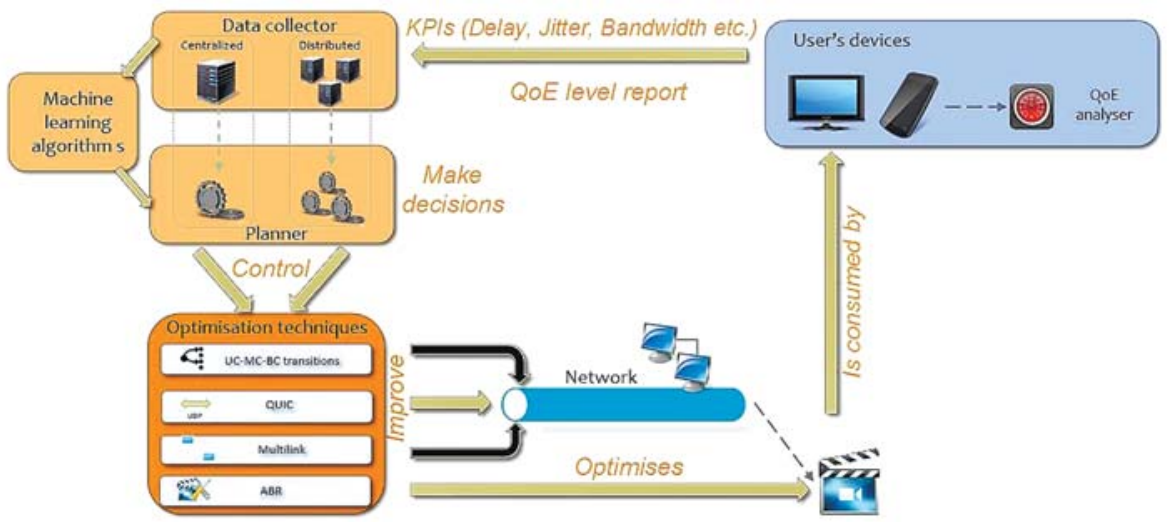

до всесвітньої павутини, та вимоги щодо кількості абонентів, швидкості мобільного доступу до ресурсів мереж зростають з кожним роком. Розробники телекомунікаційного обладнання та оператори зв'язку, прагнучи відповісти на нові виклики [3], готуються серйозно змінити архітектуру мережі і правила взаємодії в ній. Як наслідок, з'являються перші розгорнуті мережі 5G. Їх дослідження, узгодження та розвиток відбувалися відповідно до «дорожньої карти», затвердженої організацією The 3rd Generation Partnership Project (3GPP).

Так, спочатку проводилися відповідні дослідження, а перша комерційна мережа п'ятого покоління почала працювати лише у 2018 р., коли оператор зв'язку Verizon оголосив про запуск «першої у світі мережі 5G» у чотирьох містах Сполучених Штатів Америки - X'юcтоні, Індіанаполісі, Лос-Анджелесі та Сакраменто [4]. Перша загальнонаціональна мережа 5G, що забезпечує безперервне покриття, з'явилася в Південній Кореї у квітні 2019 р. [4].

При цьому на всьому шляху становлення стільникових мереж п'ятого покоління однією 3 провідних організацій, що підтримують дослідження в цій галузі, є The 5G Infrastructure Public Private Partnership (5G PPP).

Співпрацю в рамках ініціативи 5G PРP планувалося організувати у 3-4 етапи, які охоплювали дослідження, оптимізацію (20162017 рр.) та широкомасштабні випробування технологій (2019-2020 рр.). 5G PРP мало на меті впровадити 5G 32020 р., для чого потріб- но було розробити низку новаторських технологій, глобальних стандартів та узгодити відповідні діапазони частотного спектра. Детальну інформацію про всі проєкти можна знайти на офіційному сайті 5G PPP [5, 6], а в цій статті наведено результати виконання тільки трьох проєктів за програмою «Горизонт-2020» [7], а саме: 5G-Xcast [8], 5G-TOURS [9] та 5GASP [10].

Проєкт 5G-Xcast. У рамках проєкту 5GXcast було отримано результати з удосконалення ядра мережі 5G для забезпечення можливості multicast/broadcast мовлення в цих мережах, конвергенції різнорідних мереж, забезпечення безшовного переходу між різними зонами обслуговування абонентів тощо. Ці напрацювання стосуються технологій передачі мультимедійного контенту, систем PWS (Public Warning Systems) тощо.

Консорціум проєкту 5G-Xcast розробив, оцінив і продемонстрував концептуально нову перспективну архітектуру мережі 5G для широкомасштабної доставки медіа (рис. 1). Для цієї мережі було розроблено процедури взаємодії мережевих функцій, створено технологію багатоканальної передачі даних, що дало змогу забезпечити безшовний перехід між різними сервісними зонами, наприклад між unicast i multicast та навпаки. Детальний опис усіх напрацювань наведено у звіті проєкту [11].

Загалом усі результати, отримані в рамках проєкту $5 \mathrm{G}$-Xcast, спрямовано на забезпечення можливості трансляції та багатоадресного 


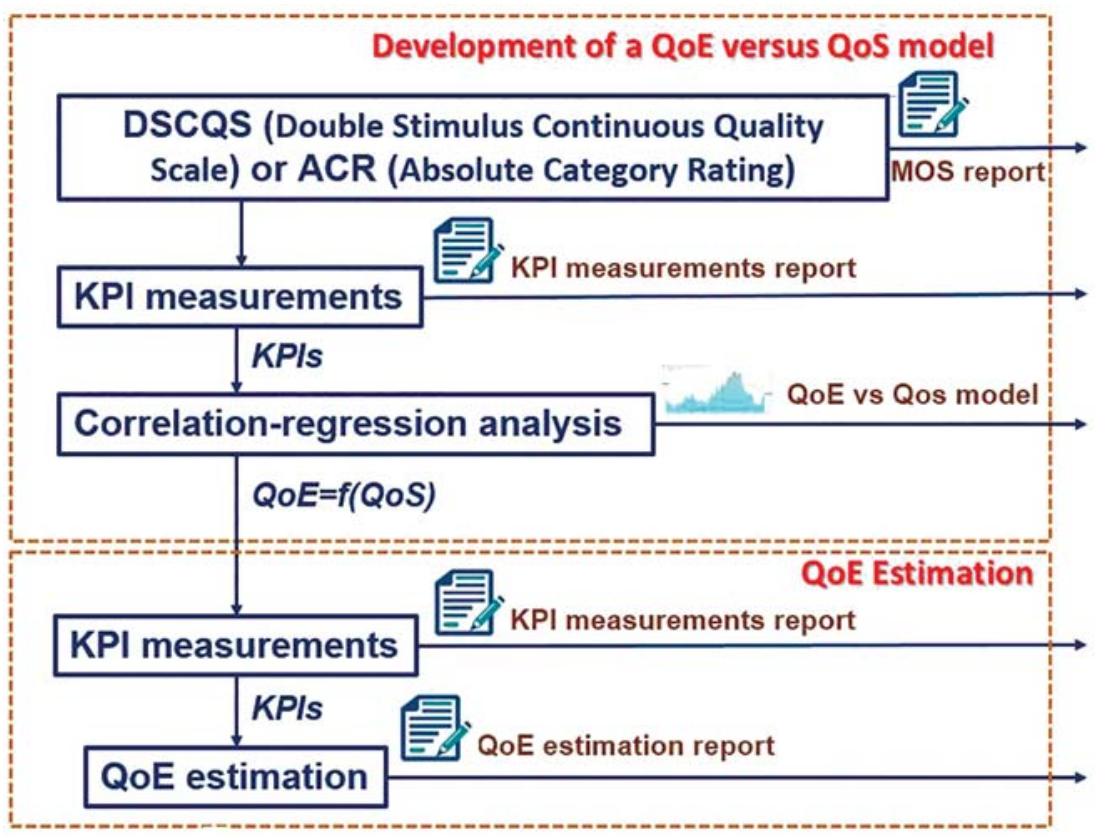

Puc. 3. Методологія оцінки QoE та QoS для стільникових мереж $5 \mathrm{G}$ передавання point-to-multipoint (PTM) для стільникових мереж 5G для таких сфер використання, як засоби масової інформації, розваги, автомобільна індустрія (V2X), «Інтернет речей» (IoT) та PWS. Також було проведено оцінку варіантів розподілу спектра 5G для розгортання мережі $5 \mathrm{G}$ Broadcast.

Крім того, розроблено динамічно адаптовану мережеву архітектуру 5G з незалежними від шару мережевими інтерфейсами для динамічного і плавного перемикання між одноадресними, багатоадресними та широкомовними режимами або для паралельного їх використання чи використання вбудованих можливостей кешування (рис. 2).

Під час апробації розроблених рішень було експериментально продемонстровано ключові нововведення 5G, реалізовані в рамках проєкту для медіа та розваг, та вертикалі PWS [12].

Проєкт 5G-TOURS. Основна мета проєкту 5G-TOURS (smarT mObility, media and ehealth for toURists and citizenS) - поліпшити життя в місті для його мешканців та туристів, зробивши міста привабливішими для відвідування, ефективнішими з точки зору мобільності та безпечнішими для всіх.
Проєкт 5G-TOURS присвячено тестуванню стільникових мереж 5G на прикладі 13 відібраних високоінноваційних випадків використання для трьох різних типів міст:

- туристичне місто (Турин, Італія) - відвідувачам музеїв та пам'яток архітектури пропонуються програми на основі 5G, додатки VR/ $\mathrm{AR}$, зокрема інтерактивні тактильні комунікаціï; туристична подорож поліпшується завдяки використанню роботів, можливості віддалених відвідувань різних заходів, подій, концертів у прямому ефірі тощо;

- безпечне місто (Ренн, Франція) - технологія 5G значно підвищує безпеку в місті, надаючи засоби для поліпшення медичної допомоги на всіх етапах лікування, починаючи від моніторингу стану здоров’я з метою профілактики та раннього виявлення захворювань до діагностики у кареті швидкої допомоги та проведення операцій у лікарні. Крім того, 5G забезпечує туристам можливість дистанційної медичної допомоги з їхньої країни;

- мобільно ефективне місто (Афіни, Греція) - переміщення всередині міста стає більш ефективним і комфортним завдяки доступу до інформації про місто, вдосконаленим систе-

ISSN 1027-3239. Visn. Nac. Acad. Nauk Ukr. 2021. (10) 

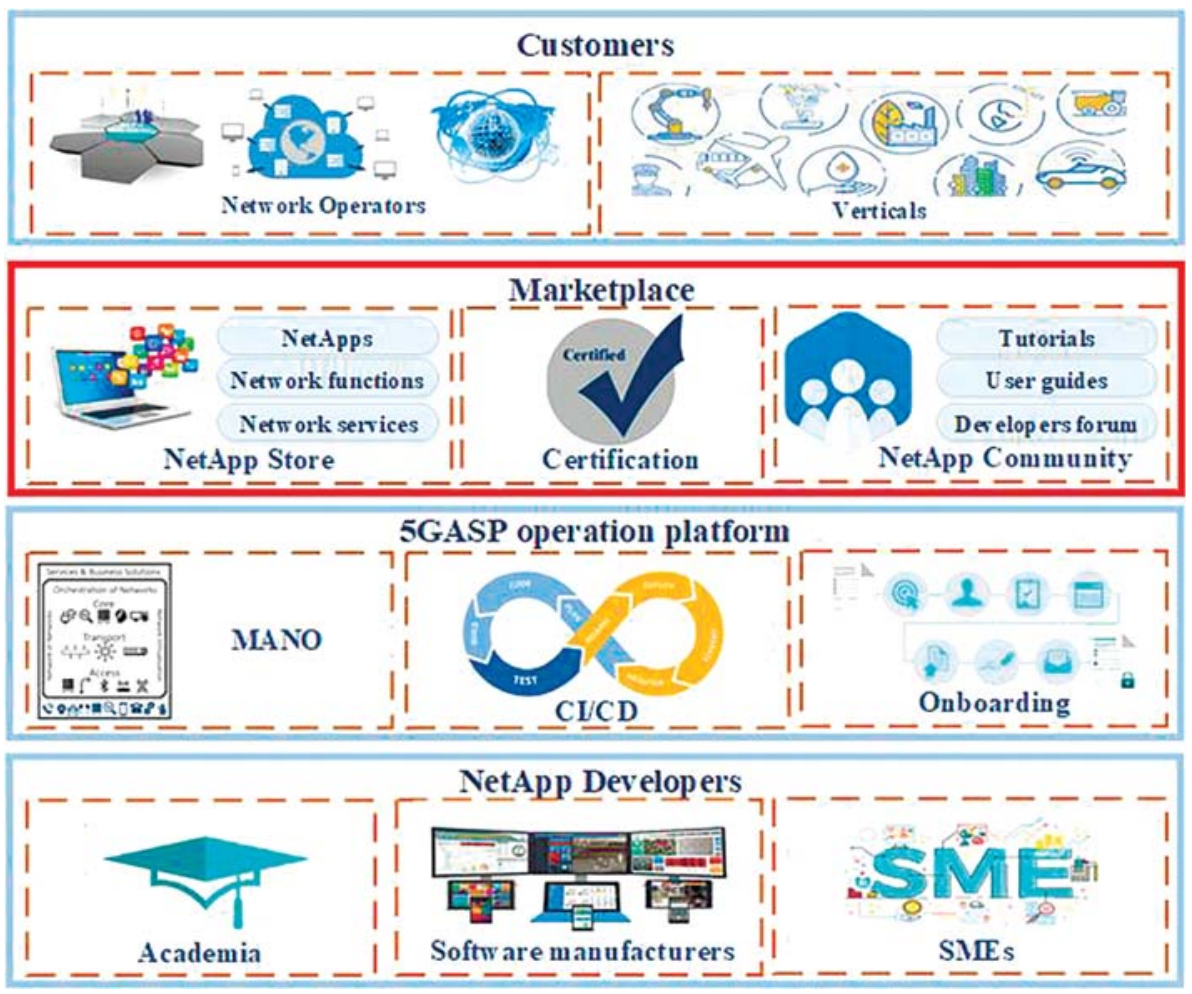

Puc. 4. Архітектура проєкту 5GASP

мам навігації, паркування, роботи аеропортів, наявності AR/VR-послуг для пасажирів міського транспорту.

У рамках цього проєкту було розроблено методологію оцінки показників QoE та QoS в стільникових мережах 5G (рис. 3). На базі запропонованих рішень триває реалізація дуже складних випадків використання і, відповідно, тестування можливостей мереж 5G, виявлення проблемних місць. Отримані результати застосовуватимуться для поширення найкращого досвіду та підтвердження основних переваг використання можливостей мереж 5G для різних вертикальних індустрій.

На нинішньому етапі проведено поки що невеликі тестування можливостей мереж $5 \mathrm{G}$ [13], а повноцінні дослідження заплановано на останній рік виконання проєкту.

Проєкт 5GASP. Оскільки технологія 5G останнім часом набула вже досить високого рівня розвитку, тестування та перевірка рішень на основі 5G стають дедалі важливішими. 3 огляду на те, що основні сфери (вертикалі) використання 5G, такі як автомобільна промисловість, громадський захист та ліквідація наслідків стихійних лих (PPDR) тощо, мають дуже різні потреби, всі процеси перенесення їніх додатків, створення послуг від концепцій до прототипів i, нарешті, готових продуктів потребують різних рівнів підтримки. При цьому все частіше у служб різних вертикалей виникає необхідність обмінюватися даними, особливо це стосується мобільних сервісів для автомобілів та пристроїв PPDR, підключених до мережі.

Саме тому проєкт 5GASP має на меті створення європейської випробувальної повністю автоматизованої платформи для самообслуговування малих і середніх підприємств, що сприятиме розвитку та підвищенню ефективності тестування нових інноваційних застосунків NetApps, побудованих з використан-

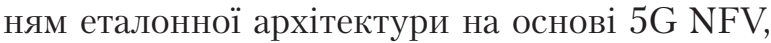
i, відповідно, уможливить скорочення часу та витрат на шляху від появи ідеї до їі реалізації на ринку. 
У рамках проєкту 5GASP планується створити уніфіковану платформу для всебічного автоматизованого тестування мережевих додатків, які розробляються для інфраструктури $5 \mathrm{G}$ (рис. 4). Ця платформа дасть змогу невеликим підприємствам - розробникам програмного забезпечення для $5 \mathrm{G}$, швидше виводити на ринок свої продукти, що сприятиме розвитку галузі інформаційно-комунікаційних технологій і загалом зростанню економіки Свросоюзу.

Отже, основними цілями проєкту є такі:

- прискорення процесів розроблення, тестування та сертифікації NetApps через створення спільної платформи, інструментів DevOps та «дорожньої карти» сертифікації;

- забезпечення розробників найсучаснішими випробувальними потужностями, за допомогою яких в економічно найефективніший спосіб можна випробовувати та перевіряти їхні розробки в різних вертикалях застосування;

- технічне впровадження інновацій, можливість розглянути випадки міждоменного використання, різні аспекти безпеки та довіри, пов’язані з розгортанням та експлуатацією NetApp;

- надання найсучасніших інструментів для автоматизованого тестування, постійний моніторинг та розширення можливостей інтеграції тестових стендів, переважно завдяки використанню програмних засобів з відкритим кодом;

- створення спільноти, в якій розробники можуть обмінюватися знаннями про 5G NetApp;

- розроблення різних бізнес-моделей, які функціонують навколо ринку NetApps i за допомогою яких усі зацікавлені сторони можуть отримувати додатковий дохід.

I хоча проєкт 5GASP розпочався зовсім нещодавно, наразі вже є окремі напрацювання і результати, з якими можна ознайомитися на офіційному сайті проєкту [14].

Висновок. Описані у статті етапи виконання трьох різних наукових проєктів - 5G-Xcast, 5G-TOURS i 5GASP - в рамках програми «Горизонт-2020» дають змогу простежити еволюцію та плавний перехід від проєктів, спрямованих на розроблення інноваційних архітектурних рішень, потім проєктів, що використовують цю інфраструктуру та доводять їі до комерційного розгортання, і до проєктів, які сприяють подальшому розвитку наявної інфраструктури та їі поширенню на різноманітні вертикальні галузі.

Слід зауважити, що всі згадані вище напрацювання відкривають можливості для руху в напрямі створення стільникових мереж уже нового, шостого, покоління - 6G!

\section{REFERENCES}

[СПИСОК ЛІТЕРАТУРИ]

1. Webster F. Theories of the Information Society. Routledge, 2014.

2. Cloud AR/VR Whitepaper. GSMA Future Networks. April 26, 2019. https://www.gsma.com/futurenetworks/wiki/ cloud-ar-vr-whitepaper/

3. Benisha M., Prabu R.T., Bai V.T. Requirements and challenges of $5 \mathrm{G}$ cellular systems. In: Advances in Electrical, Electronics, Information, Communication and Bio-Informatics: Proc. 2nd Int. Conf. IEEE (February 2016). P. 251-254.

4. 5G. ETSI. Technologies. https://www.etsi.org/technologies/5G

5. The 5G Infrastructure Public Private Partnership (5G PPP). First Wave of Research \& Innovation Projects. https://5g-ppp.eu/wp-content/uploads/2015/10/5GPPP-brochure-final-web.pdf

6. The 5G Infrastructure Public Private Partnership (5G PPP). Second Wave of Research \& Innovation Projects. https://5g-ppp.eu/wp-content/uploads/2017/11/5GPPP-brochure-phase2-final-web.pdf

7. Horizon 2020. https://ec.europa.eu/programmes/horizon2020/en/home

8. 5G-Xcast. https://5g-xcast.eu

9. 5G-TOURS. https://5gtours.eu/

10. 5GASP. https://5gasp.eu/ 
11. 5G-Xcast. Deliverable D4.1. Mobile Core Network. June 4, 2019. http://5g-xcast.eu/wp-content/uploads/2019/ 07/5G-Xcast_D4.1_v2.0_web.pdf

12. 5G-Xcast Videos. http://5g-xcast.eu/videos/

13. 5G-TOURS. https://www.youtube.com/channel/UCYdXMN027pe_Nkc6Hr92-Mw/videos?view=0

14. 5GASP. Publications. Deliverables. https://5gasp.eu/publications/deliverables.html

\section{Roman S. Odarchenko}

International Research and Training Center for Information Technologies and Systems

of the National Academy of Sciences of Ukraine

and Ministry of Education and Science of Ukraine, Kyiv, Ukraine

ORCID: https://orcid.org/0000-0002-7130-1375

\section{METHODS OF TESTING AND IMPROVING THE EFFICIENCY OF 5G CELLULAR NETWORKS}

According to the scientific report at the meeting of the Presidium of the NAS of Ukraine, September 15, 2021

To increase the efficiency of cellular networks in Ukraine, it is possible and necessary to use the already gained experience of developed European countries, while improving existing solutions and developing new ones. Thus, within the framework of two research projects under the Horizon 2020 program (5G-Xcast, 5G-TOURS) new results were obtained, which made it possible to increase the efficiency of $5 \mathrm{G}$ cellular networks. The third project has just begun, but has an ambitious goal, which is to develop a platform for automated testing and validation of applications developed for use in fifth-generation networks (5GASP). Main results obtained in the process of working on the three projects outlined above are covered in this message.

Keywords: 5G, 5G-TOURS, 5G-Xcast, 5GASP, Horizon 2020, cellular networks, efficiency increase. 